\title{
7 \\ GLOBALISATION AND GOVERNANCE: AN AFricAN PERSPECTIVE AND A CASE STUDY OF MAURITIUS
}

Vinaye Ancharaz and Sanjeev K. Sobhee

Globalisation is not a new phenomenon. What is new, however, is the dramatic scale at which it has occurred in recent years. Trade and cross-border investment, readily identified as the key drivers of 'international economic integration'-a term widely used to distinguish economic globalisation from other forms of globalisation-have registered explosive growth over the past two decades, aided by the rapid spread of information and communication technologies. Foreign direct investment (FDI) flows, which totaled US\$160 billion in 1991, rocketed to US\$1.1 trillion in 2000. The volume of international trade has increased 16-fold over the past 50 years. In the 1990s, in particular, world trade expanded much faster than world output. A remarkable feature of this growth in trade is that it was propelled mainly by trade in components, rather than in finished goods as vertically-integrated multinationals increasingly outsourced the parts they previously produced at home (Sutherland 2002).

Only the volume of controversy that it has generated in recent years matches the pace of globalisation. On balance, the accumulated evidence suggests that globalisation has proved beneficial to those economies that embraced it. A World Bank (2002) study, for example, finds that the 'new globalisers'-a group that includes Brazil, China, India and Mexico-achieved per capita growth rates that were a significant four per cent higher than countries that liberalised more slowly. Srinivasan and Bhagwati (1999) and Lindert and Williamson (2001), among others, demonstrate conclusively that promoting openness and supporting it by sound domestic policies leads to faster growth. 
Despite the positive growth effects of globalisation, there is a widespread feeling that the rising tide of trade and capital flows has increased economic vulnerability. While it is true that globalisation allows a more efficient allocation of resources based on comparative advantage-and therefore offers a fair chance to developing countries to integrate with the global trade arena-there are abundant examples of the adverse effects of (mismanaged) globalisation. Even as globalisation has promoted convergence of per capita incomes among countries, there is growing evidence that inequality within countries-both developed and developing-has increased (Masson 2001). This has raised questions about the effectiveness of globalisation strategies in alleviating poverty and raising living standards in a sustainable manner. Moreover, the kind of volatile capital flows that wreaked havoc in East Asia in 1997 remains a stark reminder of the dangers of pursuing unchecked financial globalisation.

The continuing process of globalisation has also raised a number of noneconomic concerns that have fueled the anti-globalisation sentiment. There are fears that the multinational corporatisation of economic activity has increased the incidence of child labour, harmed women, and imperiled indigenous cultures and the environment. Bhagwati (2004), however, argues that globalisation is 'socially benign' and therefore asks how governance should be designed so as to enhance the positive outcomes of globalisation.

It is expected that greater openness will lead to a larger government as the latter is called upon to play a more important role as a provider of safety nets and support services to counteract the adverse effects of globalisation. Rodrik (1996) has formalised this idea through a model in which government spending increases to absorb the heightened volatility in domestic income and consumption arising from the greater external risk induced by globalisation. Rodrik measures external risk as the variability in a country's terms of trade and argues that, although in principle small economies can diversify away from this risk by participating in international capital markets, evidence suggests that in practice this is far from the case (Lewis 1995).

Hence, the task of mitigating external risks falls on the government, but the mechanisms in place to achieve this differ markedly between developed and developing economies. In countries with demonstrated administrative capability to implement social welfare programs, the government can effectively compensate losers from globalisation through transfer payments. In most developing economies, however, the government's risk-mitigating role is limited 
to providing secure public employment, retraining facilities and, to a lesser extent, safety nets to the vulnerable. Rodrik (1996) provides empirical evidence confirming these hypotheses.

Alesina and Wacziarg (1997) question Rodrik's (1996) findings on the ground that the latter omitted a critical control variable-country size-from his basic econometric specification. They argue, with supporting evidence, that

1 larger countries have smaller governments (because the per capita cost of providing a given level of public goods, characterised by fixed costs and economies of scale, falls with size $)^{1}$

2 smaller countries tend to be more open (because they are compelled to embrace openness so as to expand their effective market size and benefit from economies of scale).

Taken together, these findings imply that more open economies have larger governments but that this relationship is mediated by country size. Alesina and Wacziarg (1997) show that, once country size is explicitly accounted for, the positive relationship between government size and openness uncovered by Rodrik (1996) no longer holds. Nevertheless, they do find evidence that the size of government transfers increases with openness, confirming Rodrik's hypothesis about the risk-mitigating role of government spending in open economies.

Against the above background, this chapter investigates the relationship between government size and openness in sub-Saharan African countries, with a special focus on Mauritius, which is often cited as a small, open economy with good governance.

\section{GLOBALISATION AND GOVERNANCE: AN AFRICAN PERSPECTIVE}

In the second half of the 1990s, sub-Saharan Africa recorded its highest rate of growth in two decades. Fischer et al. (1998) attribute this remarkable economic performance to better policies rather than to favourable external developments. Several positive changes have occurred in a number of sub-Saharan African economies during the 1990s. Many countries have implemented structural reforms and stabilisation measures, although with varying degrees of success. The region has also seen a movement toward democracy and greater political stability. 


\section{2 \\ Pacific Island Regional Integration and Governance}

Africa's economic woes are far from over, however. The magnitude of the economic decline in most African countries was such that GNP per capita in sub-Saharan Africa was lower at the end of the last decade than in 1970. Moreover, a large body of evidence suggests that sub-Saharan African economies have made little progress with economic reforms. ${ }^{2}$ The wave of democratisation also delivered less than it promised (Bratton and van de Walle 1997).

While most of sub-Saharan Africa was grappling with domestic problems, many developing countries elsewhere were taking fuller advantage of the opportunities offered by the globalisation of economic activity and the growth of world trade. The result has been the 'marginalisation' of Africa in the world economy (Collier 1995; Yeats et al. 1996). Sub-Saharan Africa's share of world exports declined from an already low 1.2 per cent in 1990 to 1.0 per cent in 2000 (Table 7.1), while its share of world foreign direct investment (FDI) flows has stagnated at 1 per cent over a comparable period (Table 7.2). SubSaharan Africa as a whole accounted for a little more than 1 per cent of world income in 2001.

In absolute terms, however, sub-Saharan Africa saw a significant increase in trade and FDI flows in the 1990s. The region has made a decent effort to catch the globalisation wave-a number of countries have successfully liberalised and achieved degrees of openness comparable to the 'new globalisers'. ${ }^{3}$ In this section, we investigate the impact of globalisation on governance in sub-Saharan Africa using a simple reduced-form regression model. The primary hypothesis, motivated by the literature surveyed above, is that greater openness leads to a larger government that acts as a buffer against the disastrous consequences of globalisation.

The basic regression is

$$
\mathrm{G} / \mathrm{Y}=\mathrm{g}(\mathrm{PCY}, \mathrm{DEP}, \mathrm{URBAN}, \mathrm{OPEN})
$$

where $G / Y$ is the share of government consumption spending in GDP at constant prices, $P C Y$ is real GDP per capita, DEP is the dependency ratio, URBAN is the percentage of population living in urban areas, and $O P E N$ is the degree of trade openness. Several variants of this equation are estimated to verify the robustness of the findings and to test alternative hypotheses. Thus, population $(P O P)$ and terms-of-trade risk $(T O T R)$ are introduced as explanatory variables subsequently. 
Table 7.1 Sub-Saharan Africa in world trade, 1990-2000 (per cent)

\begin{tabular}{|c|c|c|c|c|c|c|c|c|}
\hline & \multicolumn{4}{|c|}{ Exports } & \multicolumn{4}{|c|}{ Imports } \\
\hline & & & $\begin{array}{l}\text { Change } \\
\text { in market }\end{array}$ & $\begin{array}{c}\text { Average } \\
\text { annual }\end{array}$ & & & $\begin{array}{l}\text { Change } \\
\text { in market }\end{array}$ & $\begin{array}{c}\text { Average } \\
\text { annual }\end{array}$ \\
\hline & 1990 & 2000 & share & growth & 1990 & 2000 & share & growth \\
\hline Developed economies & 71.5 & 64.0 & -7.5 & 5.5 & 72.5 & 67.3 & -5.2 & 5.7 \\
\hline Developing economies & 23.9 & 32.0 & 8.1 & 9.1 & 22.6 & 29.1 & 6.5 & 8.3 \\
\hline Asia and the Pacific & 16.9 & 24.2 & 7.3 & 9.5 & 15.9 & 21.1 & 5.2 & 8.2 \\
\hline \multicolumn{9}{|l|}{ Latin America and the } \\
\hline Caribbean & 4.2 & 5.6 & 1.4 & 10.2 & 3.7 & 5.9 & 2.2 & 11.4 \\
\hline Sub-Saharan Africa & 1.2 & 1.0 & -0.2 & 4.1 & 1.1 & 0.8 & -0.4 & 2.6 \\
\hline Transition economies & 4.6 & 4.0 & -0.6 & 8.8 & 4.9 & 3.6 & -1.3 & 8.7 \\
\hline
\end{tabular}

Note: South Africa is treated as a developed economy.

Source: UNCTAD, 2003. Handbook of Statistics, UNCTAD, New York..

Table 7.2 Foreign direct investment flows, 1991-2000

\begin{tabular}{|c|c|c|c|c|c|}
\hline \multirow[t]{2}{*}{ Host region } & \multicolumn{2}{|c|}{$\begin{array}{c}\text { 1991-96 } \\
\text { (Annual average) }\end{array}$} & \multicolumn{2}{|c|}{2002} & \multirow{2}{*}{$\begin{array}{c}\text { Change in } \\
\text { share } \\
\text { (per cent) }\end{array}$} \\
\hline & $\mathrm{US} \$ \mathrm{~m}$ & Per cent & US\$m & Per cent & \\
\hline World & 254,326 & 100.0 & 651,188 & 100.0 & - \\
\hline Developed economies & 155,091 & 61.0 & 461,088 & 70.8 & 9.8 \\
\hline Developing economies & 91,052 & 35.8 & 161391 & 24.8 & -11.0 \\
\hline Asia and the Pacific & 59826 & 23.5 & 95129 & 14.6 & -8.9 \\
\hline Latin America and the & & & & & \\
\hline Caribbean & 27069 & 10.6 & 56019 & 8.6 & -2.0 \\
\hline Sub-Saharan Africa & 2542 & 1.0 & 6698 & 1.0 & - \\
\hline Transition economies & 8183 & 3.2 & 28709 & 4.4 & 1.2 \\
\hline
\end{tabular}

Note: South Africa is treated as a developed economy.

Source: Author's calculations using data from UNCTAD, 2003. Handbook of Statistics, UNCTAD, New York..

The data are taken from the World Bank Africa Database 2002. All the variables, except terms-of-trade risk, are measured as averages over the period 1996-2000; TOTR is calculated as the standard deviation of terms of trade over the same period. The full sample comprises 42 sub-Saharan African countries for which reasonable data were available; the sample size falls to 38 countries when TOTR is accounted for. 


\section{Pacific Island Regional Integration and Governance}

The estimation results are reported in Table 7.3. In columns 1-3 of the table, the dependent variable is the share of government consumption in GDP.

Despite some notable departures, the results are broadly supportive of Rodrik's (1996) primary hypothesis. The coefficient of per capita income is positive and statistically significant at conventional levels (except in column 3), contrasting with both Rodrik (1996) and Alesina and Wacziarg's (1997) findings, but supporting Wagner's law. The dependency ratio is positive as expected but never significant. Conversely, urbanisation enters with a negative sign in all variants of the basic regression and is significant at the five per cent level or better.

Let us now turn to the estimated coefficients on openness, our key variable. Consider the results of column 1 to begin with. When openness is included

Table 7.3 Regression results

Independent variables

Dependent variable

\begin{tabular}{lcccc} 
& $\log (G / Y)$ & $\log (G / Y)$ & $\log (G / Y)$ & $\log (P C G)$ \\
& $(1)$ & $(2)$ & $(3)^{\S}$ & $(4)$ \\
Constant & $-7.241^{* *}$ & $-7.337^{* *}$ & $-7.338^{* *}$ & $-7.277^{* *}$ \\
& $(3.07)$ & $(3.35)$ & $(4.55)$ & $(3.09)$ \\
$\log (\mathrm{PCY})$ & $0.232^{* *}$ & $0.234^{* *}$ & 0.194 & $1.234^{* * *}$ \\
& $(0.100)$ & $(0.104)$ & $(0.139)$ & $(0.101)$ \\
$\log (\mathrm{DEP})$ & 0.657 & 0.658 & 0.579 & 0.662 \\
& $(0.591)$ & $(0.599)$ & $(0.682)$ & $(0.593)$ \\
$\log (\mathrm{URBAN})$ & $-0.349^{* *}$ & $-0.350^{* *}$ & $-0.326^{* *}$ & $-0.352^{* *}$ \\
& $(0.158)$ & $(0.161)$ & $(0.147)$ & $(0.158)$ \\
$\log ($ OPEN $)$ & $0.470^{* * *}$ & $0.476^{* * *}$ & $0.539^{*}$ & $0.472^{* * *}$ \\
& $(0.168)$ & $(0.187)$ & $(0.317)$ & $(0.169)$ \\
$\log ($ POP $)$ & & 0.004 & 0.019 & \\
& & $(0.051)$ & $(0.080)$ & \\
TOTR & & & 1.383 & \\
& & & $(6.446)$ & \\
$\log ($ OPEN)*TOTR & & & -0.254 & \\
& & 0.237 & 0.125 & 0.896 \\
Adj. R-squared & 0.258 & 3.56 & 1.76 & 89.1 \\
F & 4.57 & 42 & 38 & 42 \\
No. of observations & 42 & & & \\
\hline
\end{tabular}

Notes: Standard errors in brackets. ${ }^{* * *}$ significant at 1 per cent; ${ }^{* *}$ significant at 5 per cent; ${ }^{*}$ significant at 10 per cent. ${ }^{\S}$ Heteroscedasticity-consistent standard errors. 
without controlling for country size $(P O P)$, the regression yields a positive and highly significant coefficient on the variable. The results imply that a one percentage-point increase in the trade-GDP ratio is, on average, associated with about a half percentage-point increase in the share of government consumption in GDP. This seems to be an important response by governments of sub-Saharan African countries to the challenges posed by globalisation. ${ }^{4}$

The results of column 2 are obtained when POP is explicitly introduced as an independent variable in the regression. Interestingly, this variable displays no statistical association with government size, contrary to Alesina and Wacziarg's (1997) claim that country size is a critical intervening variable in the relationship between government size and openness. Moreover, comparing the results of columns 1 and 2, we observe that the addition of POP does not affect the estimated coefficients of the baseline regression either in magnitude or in statistical significance. However, the sharp drop in the goodness of fit and in the F-statistic does suggest that country size is a redundant variable in the model specification.

In column 3, we have included two additional variables-terms-of-trade risk $(T O T R)$ and the latter interacted with openness. The objective is to determine whether government size increases with globalisation because greater openness exposes a country to larger terms-of-trade shocks. The results suggest that this has not been the case in sub-Saharan Africa. The openness variable, however, remains statistically significant, albeit at the reduced 10 per cent level.

One interpretation of the above findings is that governments have grown in sub-Saharan Africa to protect their citizens against the many detrimental effects of globalisation, but that these effects have not included adverse changes in the countries' terms of trade.

Column 4 shows the results of estimating Equation 7.1 with government consumption per capita $(P C G)$ substituted for $G / Y$. This variant of the regression is intended to serve as a robustness check. A notable finding is that income per capita, which had become insignificant in column 3, reasserts itself as an important determinant of government spending per capita, with an elasticity exceeding unity. Openness regains its former 1 per cent significance. On the whole, the results corroborate the findings reported earlier. ${ }^{5}$ 


\section{INSTITUTIONAL REFORMS, GOVERNANCE AND GLOBALISATION IN MAURITIUS}

In this section an exclusive investigation of the impact of globalisation on the size of the public sector in Mauritius over the post-independence period 19702000 is made. Mauritius has pursued a policy of outward-oriented industrialisation ever since its import-substituting strategy collapsed in the 1960s. In recent years, however, as the process of globalisation has gathered momentum, threatening to damage economic prosperity and livelihoods, the government of Mauritius has implemented a series of institutional reforms and set up compensation mechanisms in all the major sectors of economic activity to tackle the challenges posed by globalisation.

In the agricultural sector, the Voluntary Retirement Scheme has been introduced to encourage workers to opt for an earlier retirement, with attendant benefits. The scheme's objective is to enable the overstaffed sugar industry to downsize its workforce, cut back labour costs and achieve greater efficiency so that it can stand ready to face the cut-throat competition that would follow the eventual phasing out of the Sugar Protocol—of which Mauritius has long been a privileged beneficiary. Moreover, large-scale land reforms have allowed conversion of thousands of acres of agricultural land for commercial and residential purposes. A notable initiative in this area is the Integrated Resort Scheme, which seeks to attract foreign investors by offering them the possibility of acquiring immovable property in Mauritius. This scheme has led to the clearing of land under sugar cane cultivation to make room for the construction of luxury villas and hotel complexes.

In the manufacturing sector, the government has recently put in place a scheme to compensate workers who have lost, or would be losing, their jobs as a result of the dismantling of the Multifibre Agreement. Similarly, the Textile Support Emergency Team has been set up to advise struggling firms on the structural measures that they should take-again with assistance from the government - to survive the erosion of trade preferences. Moreover, a Clothing Technology Centre has been established to provide export processing zones using firms up-to-date knowledge on technology choices, with a view to upgrading technology in the textile and clothing industry.

The government of Mauritius has played an important role at the international level in trade negotiations on market access for both agricultural and manufactured products to safeguard the interests of the local business 
community but also to prevent further job losses and to delay unpalatable structural reforms. Indeed, Mauritius has been an ardent defender of the interests of small island developing economies, arguing that such economies deserve special and differential treatment in international trade to enable them to compete effectively with other countries. The government has also led a relentless battle for the preservation of the Sugar Protocol and, recently, for the extension of the third-country fabric derogation under the African Growth and Opportunity Act. The high-profile involvement of Mauritius in trade negotiations has called for massive government spending, both in terms of investment in training for negotiators and diplomats, and financing of missions abroad.

As regards the services sector, the government has taken steps to diversify the range of services that have traditionally been the bedrock of the Mauritian economy towards emerging services such as Freeport operations, offshore banking and financial services, and business process outsourcing. The government recognises that, in an economy with no natural resource endowments, with a small market and unfavourable geography, the services sector is the most promising avenue for future growth. Consequently, among a host of other measures, the government has made the firm commitment to transform the country into a 'cyber-island'. The completion of the first phase of the cyber tower at Ebene, the work-in-progress for the second phase, and the proposal to build another cybercity at Rose Belle all bear testimony to this commitment.

Empirical evidence confirms that good governance is a major driver of economic growth. Mauritius has ratified several international conventions pertaining to the rule of law, civil and labour rights, money laundering and corruption, and corporate governance, amongst others. This has led to wideranging institutional reforms and the creation of new organs of public administration, resulting in an increase in the size of government.

The above seems to indicate that the process of globalisation has imposed new commitments and responsibilities on the Mauritian government, which have caused an unprecedented increase in government spending. We now turn to a formal investigation of the relationship between government size and openness and, in the process, we expect to throw light on the dynamics of incorporating the challenges of globalisation in the domain of public policymaking. 


\section{Estimation issues and findings}

Our basic specification is as follows

$\mathrm{PCG}=\mathrm{f}(\mathrm{PCY}, \mathrm{OPEN})$

where the variables are defined as above. Since greater openness leads to deeper integration into the world economy rather slowly over time, it is useful to characterise the relationship between government size and openness as a dynamic one. We therefore study the short and long-run dynamics of this relationship using the co-integration technique.

As a routine exercise in time-series econometrics, Augmented Dickey Fuller $(A D F)$ tests for unit root are performed on the three variables to ascertain their order of integration. The results are shown in Table 7.4.

The test results suggest that, while all the variables are non-stationary in level form, they become stationary in the first difference. This implies that the variables are all integrated of one and the same order, that is, they are all $I(1)$.

Next, we use the Johansen technique to determine whether PCG and OPEN are co-integrated. Based on the Trace matrix, we find a unique co-integrating vector which links up the dependent variable and the regressors. The Trace statistic of 18.85 is found to be significant at the 5 per cent level. ${ }^{6}$

Using a general-to-specific approach, the following error-correction model (ECM) is established, in which the optimal lag length turns out to be 1 . The Banerjee et al. $(1986,1993)$ decomposition-which is particularly relevant

Table 7.4 ADF tests of unit roots

\begin{tabular}{lcc}
\hline & Computed & Optimal \\
Variable & ADF statistic & lag length \\
$\log \left(P C G_{\mathrm{t}}\right)$ & -2.9750 & 1 \\
$\Delta \log \left(P C G_{\mathrm{t}}\right)$ & $-4.5481^{*}$ & 3 \\
$\log \left(P C Y Y_{\mathrm{r}}\right.$ & -0.2912 & 3 \\
$\Delta \log \left(P C Y_{\mathrm{t}}\right)$ & $-3.4635^{*}$ & 3 \\
$\log \left(O P E N_{\mathrm{r}}\right)$ & -2.9730 & 2 \\
$\Delta \log \left(O P E N_{\mathrm{t}}\right)$ & $-3.3798^{*}$ & - \\
\hline
\end{tabular}

Notes: ${ }^{*}$ indicates significance at 5 per cent conditional on the critical value of -2.978 based on MacKinnon (1991). ' $\Delta$ ' indicates the first order difference operator. Optimal lag length is determined on the basis of Akaike's Information Criterion (AIC).

Source: Computed 
for small samples, is applied to compare the long and short-run elasticities of each of the explanatory variables. Such decomposition is not done by either the Engle-Granger method or by the Johansen technique. The latter two report only the short-run elasticity for each independent variable and the long-run disequilibrium parameter. The Banerjee et al. $(1986,1993)$ model is relevant in this context, more so because the sample size is small. Moreover, the shortrun dynamics based on AIC allow the inclusion of lagged values of all variables, leading us to accept the ECM as reported below (t-ratios in brackets)

$$
\begin{gathered}
\Delta \log \left(P C G_{\mathrm{t}}\right)=\begin{array}{cc}
7.28+0.804 \Delta \log (P C Y) & 0.0673 \Delta \log \left(O P E N_{\mathrm{t}}\right) \\
(4.28)^{* *}(4.37)^{*} & (-2.13)^{* *}
\end{array} \\
-0.74 \log \left(P C G_{\mathrm{t}-1}\right)+0.918 \log \left(P C Y_{\mathrm{t}-1}\right)-0.096 \log \left(O P E N_{\mathrm{t}-1}\right) \\
(-4.08)^{*}(3.84)^{*}
\end{gathered}
$$

$\bar{R}^{2}=0.56, \mathrm{DW}=2.1, \mathrm{~F}=8.3$ (where ${ }^{*}$ indicates significance at 1 per cent; ${ }^{* *}$ indicates significance at 5 per cent).

This equation could now be parametrised to capture short and long-run dynamics as follows

$$
\begin{aligned}
& \Delta \log \left(P C G_{\mathrm{t}}\right)=7.28+0.804 \Delta \log \left(P C Y_{\mathrm{t}}\right)-0.0673 \Delta \log \left(O P E N_{\mathrm{t}}\right) \\
& (4.28)^{* *}(4.37)^{*} \quad(-2.13)^{* *} \\
& -0.74\left[\log \left(P C G_{\mathrm{t}-1}\right)-1.24 \log \left(P C Y_{\mathrm{t}-1}\right)+0.13 \log \left(O P E N_{\mathrm{t}-1}\right)\right] \\
& (-4.08)^{*} \quad(3.84)^{*} \quad(-3.18)^{*}
\end{aligned}
$$

$\overline{\mathrm{R}}=0.56, \mathrm{DW}=2.1, \mathrm{~F}=8.3$ (where ${ }^{*}$ indicates significance at 1 per cent; ${ }^{* *}$ indicates significance at 5 per cent).

Table 7.5 shows the elasticity values derived from the estimates. These results show that while the size of the public sector increases with per capita income

Table 7.5 Short and long-run elasticities

$\begin{array}{lcc}\text { Variable } & \text { Short-run elasticity } & \text { Long-run elasticity } \\ \text { GDP per capita }(P C Y) & 0.8 & -1.24 \\ \text { Openness }(O P E N) & -0.067 & 0.13\end{array}$


in the short run, this tendency is reversed in the long run, with a much larger effect. On the other hand, openness appears to cause a decrease in government spending per capita in the short run; over the long run, however, government size increases with openness. It is worth noting that both the magnitude and the sign of the openness elasticity change when the dynamics are accounted for. The coefficient of adjustment of -0.74 indicates that public spending adjusts rapidly to its long-run equilibrium level following any random deviation from the established long-run relationship.

To conclude, the evidence suggests that globalisation has caused an expansion of the public sector in Mauritius in the long run. This result is robust to the inclusion of a significant control variable-per capita income. Hence, it appears that the government of Mauritius is well set to address the challenges of globalisation through its policies and compensation schemes.

\section{CONCLUSION}

The relationship between openness and government size has recently generated significant interest and controversy in the literature. While it is reasonable to argue that the government, as a provider of social security and protection in socialist countries, should naturally grow bigger as it is called upon to play a more prominent role to cushion the adverse effects of globalisation on the domestic economy and its people, the accumulated evidence to date has been, at best, inconclusive.

This chapter set out to study the impact of globalisation on governance in sub-Saharan African countries, Mauritius in particular. The findings strongly suggest that greater openness has led to an expansion of the government both in sub-Saharan Africa and in Mauritius. For sub-Saharan Africa, this result is robust to the inclusion of a wide set of control variables. Further analysis indicates that the relationship between government size and openness is mediated neither by country size nor by terms-of-trade risk. Hence, sub-Saharan African countries, irrespective of their size (as measured by population) have witnessed significant growth of their governments as they have become more open. The finding that external risk is not a significant determinant of government size in sub-Saharan Africa suggests that globalisation has affected sub-Saharan African economies in ways other than through their terms of trade. This makes sense since sub-Saharan African countries are known to have comparative advantages in specific primary products, competition in which has scarcely been affected 
by the process of globalisation. On the other hand, greater openness has compelled African governments to adopt institutional reforms and policies that have resulted in a bigger bureaucracy and higher government spending. As the case study demonstrates, this is certainly true of Mauritius. The Mauritian government has initiated a series of sectoral reforms and other measures to circumvent the adverse effects of globalisation and the consequent withering away of preferential market access. Hence, it comes as little surprise that the size of the government in Mauritius has increased significantly over the long term.

\section{NOTES}

1 On the relationship between government size and country size, see also Alesina et al. (2000) and Spolaore (2000).

2 In a comprehensive review of trade policy reform in developing countries since 1985, Dean et al. (1995:187) conclude: 'Only in Africa do we find little progress towards a liberalised trade regime. Here there have been important cases of reversal of policy, no liberalisation, or increased import impediments during this period [1985-1993]'. In a recent survey of trade liberalisation in IMF-supported programs, Sharer (1998:33) reaches a similar conclusion: 'There were no clear-cut examples of sub-Saharan African countries that have implemented the same degree of trade liberalisation on a sustained basis as in the "good practice" cases'.

3 Examples include Ghana, Mauritius, Tanzania and Uganda.

4 Note that the coefficient on openness is much bigger than those reported in either Rodrik (1996) or Alesina and Wacziarg (1997).

5 Further robustness checks were performed by running the regressions in the levels, rather than in logs, of the variables. The results (available from the authors but not reported here) overwhelmingly confirm the relevance of openness as a determinant of government size, whether or not country size is controlled for.

6 The 5 per cent critical value is 11.41 . 